\title{
En-gendering Notions of Leadership for Sustainability
}

\author{
Judi Marshall*
}

This article explores the gendering of leadership for sustainability. It first reviews the world of corporate social responsibility, illustrating how men's voices predominate in shaping discourses and practices. It is appropriate that men with access to power speak out advocating change for sustainability and yet, if this is all that happens, we risk replicating business as usual. To extend the analysis and seek more women's voices and more images associating gender, leadership and sustainability, the article reviews five novels by women authors addressing environmental issues. This exploration changes the landscape of sense-making, directing attention first to broader society rather than to organizations as the base for constructing notions of sustainability. Taking this approach, themes of social justice, equality, everyday practice, ways of knowing, embodiment and the crafts of fitting in (to nature and society) move to the foreground. These provide cues for an alternatively gendered view of leadership for sustainability.

Keywords: gender, leadership, sustainability, corporate social responsibility, fiction

\section{Challenging times}

This article starts from the assumption that we are experiencing global ecological crisis. The Millennium Ecosystem Assessment (2005, p. 1) concluded that

Over the past 50 years, humans have changed ecosystems more rapidly and extensively than in any comparable period of time in human history... This has resulted in a substantial and largely irreversible loss in the diversity of life on Earth.

\footnotetext{
Address for correspondence: *Department of Management Learning and Leadership, Lancaster University Management School, Lancaster University, Lancaster LA1 4YX; e-mail: judi.marshall@lancaster.ac.uk
} 
Species extinction rates and loss of biodiversity have increased dramatically. Approximately 60 per cent of the ecosystem services humans rely on ('including fresh water, capture fisheries, air and water purification, and the regulation of regional and local climate, natural hazards, and pests', p. 1) are being degraded or used unsustainably. Often costs of degradation are shifted from one group of people globally to another or deferred to future generations. (Already in this source, demarcations are at issue, as they are below. Change is considered for its impacts on human well-being, appealing to self-interest to protect 'ecosystem services'. The Report's Preface does note that people are integral to ecosystems and may consider species and ecosystems as of intrinsic value.) Also offering warnings, the Intergovernmental Panel on Climate Change Reports (2007) are clear, stark and urgent in their messages that climate change is escalating, that anthropogenic contributions have been proved and are significant and that our planet is on the brink of irreversible effects. I will not seek to prove this situation, although I recognize that these can be perceived as contested issues. But I see 'All [current] academic debate ... [as taking] place under the pressure of knowing that the very planet is under threat of imminent destruction' (Cooper, 1992, p. 17).

In this context, this article explores the gendering of leadership relevant to sustainability. It questions boundaries, frames and definitions. What kinds of leadership are relevant in a world experiencing biodiversity destruction and climate change? Where can we seek them? As method, I have followed a path of unfolding inquiry, not anticipating at the outset where it would lead me. This article is a sequel to explorations in Marshall (2007).

Here, I first review the world of corporate social responsibility (CSR) that has emerged rapidly since the late 1990s as business's response to environmental challenge, outlining potential gender dynamics. Data suggest that women and men leaders are largely placed differently, with differential access to influencing meanings, discourses and practices (Marshall, 2007). These gender patterns are skewed rather than clearly demarcated. In relation to organizations and CSR, men's voices predominate. Some potentially significant women can be seen as speaking from the margins, advocating revisions to broader society as well as business.

It is no surprise that CSR might mirror more pervasive societal gender dynamics (Acker, 1990). But, with a few exceptions (Coleman, 2002; Grosser, 2009; Marshall, 2007), the gendering of corporate responsibility is little discussed. In a second phase of inquiry, this article therefore seeks to extend analysis by crossing boundaries. It turns to women's novels that address environmental issues for alternative perspectives of relevance to leadership for sustainability. Taking fiction as a legitimate source in this way (Czarniawska, 2006) engages with issues of voice, form and ways of knowing that are mirrored in this article. My purpose is to proliferate images as a way to retexture what is being omitted in organizational literature related to sustainability. With Cooper (1992), a feminist accountant who challenges 
the inappropriateness of trying to account for ecology in economic terms, and the complicity of accounting as a profession in such a move, I see this as political, feminist, work - speaking for diversity in its widest sense. I therefore seek to generate multiple strands of potential relevance rather than a narrowly contained analysis. This raises issues of style and voice. These affect the whole article but are especially relevant in its second phase, as mine is not a sequential, scientific style, identified by Czarniawska (2003) as a dominant form in organization theory. I aspire instead to styles Czarniawska calls poetic - involving 'disciplined imagination' (Weick, 1989, p. 516 quoted in Czarniawska, 2003, p. 244), combining ambivalence and authority in a mutually deconstructing dance - and revolutionary, promoting ambiguity. While, sadly, aspirations do not ensure craft, declaring them explains the different textures in this article.

Before proceeding I briefly consider potential meanings of sustainability. This is an open term, indicating a hoped for future state in which humans live without permanently damaging the ecosystems in which they are embedded, for example, in Hawken's (1993) restorative economy. Sustainability is thus an aspiration, an invitation to discovery, as we seek to exist within our planet's resources. Notions of deep ecology and of the self-regulating systems of Gaia are relevant here (Harding, 2006; Lovelock, 2006). But we are currently operating beyond the earth's carrying capacity (Meadows et al., 2004; Rockström et al., 2009) and are exponentially increasing our demands on it. Thus the notion of sustainability poses dilemmas. Commentators offer criteria by which we might know a sustainable society. For example, Porritt (2007) advocates the appropriate balancing of five notions of capital - natural, human, social, manufactured and financial. Monbiot reports the need for radical changes to our daily way of life, for example, requiring 'rich nations to cut their greenhouse gas emissions by $90 \%$ by 2030 ' even to slow global temperature rises (Monbiot, 2006, p. xii). In this article, I seek other images for sustainable society by attending to gender.

\section{Reviewing formulations of CSR}

Organizations' adoption of CSR is one response to societal concerns about environmental sustainability and social justice. The speed of CSR's formulation may be some indication of the importance of the issues at stake, but also of the challenge they pose to established notions of business. Attempts to adopt 'triple bottom line' accounting, paying attention to financial, environmental and social indicators and producing associated annual CSR reports (Elkington, 1997) have been a key activity, informing the UN Global Reporting Initiative. How well it engages with the challenges is open to question (Henriques and Richardson, 2004). 
Formulating CSR is a form of leadership, a definitional bid. It can imply that organizations have issues of environmental sustainability and social justice in hand, are capable of providing sufficient remedy for the degenerative aspects of capitalism itself. This is a bold attempt. Many CSR activities are skilful and impressive, opening up potential for change. But CSR itself is an inherently limited framing. For example, counting and measuring (as in CSR reporting and carbon accounting) may give numerical values to environmental and social issues so that they can be incorporated into decision-making. This provides valuable devices for focusing our attention, helping us name, manage and potentially value. But we should remember that they are also still an artifice, especially if monetary values are then attached. For 'the higher is reduced to the level of the lower and the priceless is given a price' Schumacher, 1993, p. 31).

All it can do is lead to self-deception or to the deception of others; for to undertake to measure the immeasurable is [logically] absurd ... what is worse and destructive of civilisation is the pretence that everything has a price ... that money is the highest of all values. (Schumacher (1993, p. 31)

Taking this approach treats the ecosystem as a subset of the economy rather than the reverse. Interrogating accounting from feminist theory, Cooper (1992) argues that nature has been treated as 'Outside' (an externality), and that any attempt to bring 'it' inside, accounting against notions of 'efficiency', means 'forcing nature's multiplicity into accounting's binary oppositions' (Cooper, 1992, p. 26). She agrees with d'Eaubonne (1974) that 'the profit motive itself ... has led to the destruction of the environment' (Cooper, 1992, p. 26).

Current approaches to CSR tend to individualize what must be systemic in practice, for example, placing responsibility at corporate, individual citizen and household levels for moderating environmental impacts that are regional, national and global, and are embedded in complex webs of practices, assumptions, mental models and structures. While the advocated actions are valuable and necessary, they are insufficient. Their framing does not adequately question current delineations of business and (consuming) society or patterns of power (Hardy and Clegg, 1996). Leading social and environmental accounting scholars conclude:

It looks exceptionally likely that the current form of capitalism is not sustainable - it is, after all, based on private property rights, growth and expansion, competition, maximising consumption of non-essentials, maximising returns to shareholders and directors and so on. (Gray and Milne, 2004, p. 73).

They argue that as sustainability is a system concept, it would be 'profoundly implausible that an individual company could be sustainable (or responsible) in an unsustainable (or irresponsible) system' (Gray and Milne, 2004, p. 73). 
In this fundamentally challenging context I seek to explore the gendering of leadership. How we understand leadership in relation to sustainability is a vital strand in any attempts at change, especially in view of what can be termed symbolic and structural dimensions of power (Acker, 2004; Hardy and Clegg, 1996).

No one frame of gender analysis will do justice to this venture. How to make sense of current global issues is itself a major conundrum, challenging our forms of understanding. I am therefore interested in what contributions different genres of feminism might make, for example, drawing on Calás and Smircich's (2006) critical mapping of feminist theorizing on organization studies. I suggest that we might set different perspectives alongside each other, for the intersecting insights they offer. Given the complexities of the issues involved, any readings might, for example, be valuably informed by three, not necessarily harmonious, views: (a) structural analyses of inequality and its replication (especially in capitalist societies) and symbolic, processual approaches; (b) fluid appreciations of power, language and representation; and (c) hybrid, embodied, materialist perspectives. Calás and Smircich depict these, respectively, as socialist, poststructuralist/postmodern and transnational/(post)colonial feminisms. Also, while I would rather avoid the dismissive accusation of essentialism, I note what such an accusation can seem to proscribe - including speaking from women's lives and for relational practice, care and embedded relationships with the natural world as qualities of humanity (Plumwood, 2002). In relation to sustainability especially, I think some affirmation of these can allow us to challenge mainstream formulations of issues, such as those of CSR.

I started this exploration with an interest in how - or whether - women are contributing to public debate and action in relation to sustainability (Marshall, 2007). Given the severity and urgency of the issues involved, I am concerned about what roles women are playing; and if and how their voices count (Cooper, 1992; Waring, 1988); whether they are influential and are shaping discourses and problem-solving. These are symbolic as much as representational issues (Alvesson and Billing, 2009). Male domination of a field is a cue for critical questioning rather than a simple stereotyped explanation. But distinguishing public from private worlds is problematic, a political act. It allows, for example, for-profit companies to deny responsibility for issues they consider to be externalities, such as the reproduction on which they rely to serve production (Acker, 2004). The inquiry in this article leads me back to issues of demarcation.

\section{Exploring the gendering of leadership in corporate responsibility}

Men's voices dominate in corporate and policy arenas connected to corporate responsibility, echoing gendered hierarchical patterns (Acker, 1990). But this is not a simple picture (Marshall, 2007). Some women are significantly 
involved, but they are in a minority. The predominance of men in senior positions is illustrated in the gender balance at CSR events, which mainly feature an assembly of male Chairs and CEOs speaking about their organizations' policies and activities. For example, in the UK in 2008, May Day climate change summits were held. There were 12 in regional centres, linked by satellite to a core event in London. These were promoted by $\mathrm{HRH}$ the Prince of Wales and the Business in the Community Network (BITC), whose members have committed to contributing to public good through their corporate responsibility activities (Business in the Community, n.d.). May Day was chosen as it is the international distress call - 'everyone who can should come and help'. At the Manchester venue there were nine speakers, including one woman, the regional director of BITC, who introduced the event. The CEOs of two major organizations pledged their commitment to action on climate change. In London, the nine speakers were all men: $\mathrm{HRH}$ the Prince of Wales, the Prime Minister Gordon Brown, Jonathan Porritt (CEO of a charity promoting sustainable development and the then Chair of the UK Government's Sustainable Development Commission), the Chair of the International Panel on Climate Change, a US Senator, two CEOs and one Co-chair of major organizations, and the CEO of BITC. This is a very fitting example. There are very few women who are senior enough and have sufficient dominant group credentials to advocate such a radical revision to business (Marshall, 2007). It is therefore appropriate work for senior men to be doing. But envisioned alternative notions of business in society then risk being framed only from current mindsets and the preoccupations of elite groups.

This primacy of male voices fits with the predominance of men in senior decision-making roles in business and other sectors of society. The alignment of some men with concern about climate change is significant and powerful. Those with senior and relatively secure membership credentials have more potential to challenge current models of business from within, possibly acting as tempered radicals (Meyerson and Scully, 1995; Marshall, 2007). Some figures, such as Ray Anderson, the founder and CEO of Interface, the world's largest commercial carpet manufacturer, have become icons of environmentally aware business leadership (Arena, 2004). While Anderson advocates strong environmental stewardship and can demonstrate significant reductions in Interface's environmental impacts, he also questions whether manufacturing carpets and similar products can be part of a sustainable society (Bakan, 2004). He rejects the beliefs underpinning business, which he shared before he became aware of the situation: 'that nature is unlimited, the earth [is] ... a limitless source for raw materials, a limitless sink into which we can send our poisons and waste' (interview quoted in Bakan, 2004, p. 72). In ecological terms he declares of business leaders like himself 'we're all sinners' (Bakan, 2004, p. 72).

Inside-outsiders can develop crafts of acting for change. However, such approaches are potentially precarious as well as exhilarating (Meyerson and 
Scully, 1995). This may imply pressures on men and their potential effectiveness, including challenges from norms of masculinity (Collinson and Hearn, 1994; Marshall, 2007). Dominant group members can be pressured not to champion muted interests, as Kanter's (1977) analysis of the dynamics of tokenism showed. Few women have such strong credentials in dominant power structures from which to speak, especially to advocate change (Acker, 1990). Women's potential to influence discourses or introduce new meanings and practices where they will be taken up is therefore limited. Thus CSR is becoming gendered. Men's voices are more dominant in defining organizational meanings, rhetoric and practices. And corporations dominate other societal sectors in defining how responsibility, and therefore sustainability, are being addressed (Acker, 2004; Korten, 1995).

In the business world some women who are or were significant enough to be invited to be keynote speakers are placed differently from influential men. They can be depicted as outsiders, commenting on the nature of business. Anita Roddick - entrepreneur (founder of The Body Shop International), activist, speaker, author and philanthropist (who died in September 2007) and Vandana Shiva - physicist, ecologist, activist and author - are examples. Their voices were and are raw and confronting, strong on advocacy and on expressing feelings. They take (or took) a moral responsibility to speak for the socially disadvantaged and for the environment. Their direct messages and tones might be considered by some to be going too far. But they fit Calás and Smircich's (2004, p. 479) call to value other facets of the feminine that are not about caring and reconciling differences but include those of 'the frugal housewife' and the 'hysterical woman' 'willing to 'scream in moral indignation for crimes against humanity that are constantly committed in the name of economic rationality'.

From the analysis so far, I suggest that leadership in relation to sustainability is largely held differently by women and by men (Marshall, 2007). This can be associated with questions about the territory of legitimacy. Figures such as Roddick and Shiva seek to change the landscape in which we make sense of business and its activities, to place these in a broader perspective and to associate them clearly with issues of social justice.

\section{Proliferating women's voices on sustainability}

Pondering how women do speak in ways relevant to sustainability and climate change took me to fiction, to novels which have had lasting impressions on me. This was initially an intuitive move as I noted how evocative and provocative these sources were, bringing me experiences of sustainability challenges, in contrast to the distanced accounts in most CSR literature. As I engaged, however, I warmed to the notion of proliferating gender-associated images relevant to leadership and the challenges of sustainability and offering these as 
complements to more sanitized portrayals. I wanted to speak for diversity and multiplicity (Cooper, 1992) and thus question the boundaries of legitimacy in discussing CSR, to enlarge the scope of debate and perception of choices.

Novels are not, of course, the only potential source of women's voices on sustainability. Eco-feminism (such as Plumwood, 2002) is of obvious relevance, as is Rachel Carson's (1962) highly influential Silent Spring. But fiction expands the field of view, questions framings and poses dilemmas from different perspectives. Czarniawska (2006) outlines various reasons why using fiction is a valuable possibility for researching elusive and potentially contentious gendering practices. 'Fictional texts are always, although not always simply, reflective of societies in which their authors have been raised' (Czarniawska, 2006, p. 249). They can thus be subjected to scrutiny as can other narratives from the field.

In novels I have encountered a range of challenging (to me - see below), diverse, rich, reflective women's voices, opening up and questioning issues relating to sustainability that seem masked in mainstream, gendered organizational literature. In taking this analytic move, the framing of issues changes, concerns of corporate responsibility are set in a wider social context and fundamental questions are raised about the nature of society in broad terms. The novels offer their critiques and, in some cases alternative proposals.

I therefore next explore five novels in a necessarily selective analysis. As method, I have reread each book and identified strands I think relevant to gender, leadership and sustainability, based on my history of feminist concern. These are not all explicitly marked as gender in the novels, which are seldom didactic, as an academic text might be. Rather, themes relevant to gender and power are integrated, entangled and nuanced. I seek to explicate but not separate them, wanting to tease gender out by making potential connections rather than pinning it down.

Seeking a voice, a style, for this section of the article, I wanted to offer some qualities of the novels: mirroring the immediacy, evocative imagery and subtle questioning that I found in them to bring interesting, potentially provocative and resonant, material into this space. I wanted to open and portray, not push to conclusion. I regret that as novelistic writer I have achieved only a pale offering.

But, a final qualification, who might these images challenge? It is those in the affluent world, wherever they are located in the globe, but especially in the North, living carbon-intensive lives. The dynamics depicted are everyday reality for some global citizens, the 'others' onto whom the Millennium Ecosystem Assessment Report (2005) noted that costs of ecosystem degradation might be shifted. This is not, then, a distant world but it may be unimaginable or frightening for affluent people who want to keep their/our way of life.

The five novels are The Memoirs of a Survivor (Lessing, 1976), Woman on the Edge of Time (Piercy, 1979), Mara and Dann (Lessing, 1999), Prodigal Summer 
(Kingsolver, 2000), and Oryx and Crake (Atwood, 2004). The books evoke the situations portrayed, showing them through rich accounts and creating them in imagination, a quality of analogical resonance (Marshall, 2008), rather than only describing them. Such writing can engage the senses and create a richer understanding. Thus, all the books impacted on me in more than intellectual ways. I felt their messages and experienced the world through their frames and language. To honour this dimension I seek to bring some sense of the novels into this article, to provide detail and a rhythm in my accounts that shows as well as describes them. The order in which the novels are explored links themes into a loosely structured analysis seeking to proliferate images associating gender, leadership and sustainability.

\section{Mara and Dann by Doris Lessing (1999)}

This novel was chosen because it depicts a threatening world in which people are migrating because of environmental pressures, and raises questions of how we see and know. Mara and Dann are victims of a palace coup. Forced to flee from home and family, they are raised in a poor rural village. Later they join the mass human migration northwards, away from the devastating drought. Their detailed adventures, together and separately, are complex. As girl and boy their experiences and vulnerabilities differ: as they are placed differently in the environments they encounter, pressures on them exacerbate gendered role-taking. They are befriended and betrayed, they travel and pause, staying in more and less hospitable environments. This is a world of tribes and factions; a natural world under extreme pressure; drought; limited resources, over which people fight; threatening wild animals; a built environment that seldom functions as it once did; implements from technically sophisticated past times no longer work and earlier societies' knowledge is now lost.

Mara and Dann have been trained to pay attention. As children they were asked 'What Did You See?' prompting them to notice their sense-making in order to report back. As they grew, the questions became more demanding. They realized that others saw things differently, and that shared impressions give a fuller picture than those of one person alone. As they travel, noticing what is going on around them is a vital survival skill.

This novel portrays mass migration resulting from environmental pressures, and explores associated social issues and tensions. It creates the experience of displacement and potential threat. I feel the blighted landscape. I feel what it might be like to have one vital bottle of water, to be traveling alongside others but disconnected, knowing someone might try to steal the water in the night, and kill me if that is necessary.

Making connections with gender, leadership and sustainability. Mara and Dann questions how we see the world, through the training in paying attention the 
two young people receive, and through its unrelenting portrayal of lands and 'civilizations' laid waste. What forms of knowing are helpful in a world so stressed? Rationality and understanding from a detached distance are inadequate recourses (Plumwood, 2002). Can we, instead, sensuously and viscerally, encounter what is happening now, environmentally and in terms of global social injustice (a euphemism for poverty, child mortality, water shortage, death from cholera and more), and not look away? Are we currently deflecting our senses, moving straight from denial to despair (Gore, 2006)?

But beholding ecological collapse, the part we play in it and the uncertainties of how radically and urgently we should or can change our lifestyles and forms of society, is no easy undertaking. Discussions of how to work with grief and pain are not, however, prominent in corporate responsibility literature. Environmental and CSR managers are assumed to engage rationally and unemotionally with their work and the confronting data they encounter. Joanna Macy addresses what it means to live at this time. Drawing on systemic thinking and Buddhism, respecting intellect and affect, she offers practices for encountering potential grief and finding ways still to act - Coming Back to Life (Macy and Brown, 1998). Her influence is in a different realm from that of corporate CEOs who pledge action on climate change. She challenges the boundaries of our attention. Academia privileges intellectual knowing. While emotions are now becoming an accepted aspect of organizational studies and emotional intelligence is advocated, how richly expressive is this channel of knowing allowed to be? Is some element of co-option inevitable?

As another thread, Mara and Dann offers a range of positions to identify with in the hypothetical societies portrayed. The plot suggests that leadership and power in a wasteland or resource-scarce, over-crowded urban environment will often go to those operating from approaches of might, violence or deception. Can we cultivate capacities for endurance, resilience and connection to cope with such situations?

\section{Oryx and Crake by Margaret Atwood (2004)}

This novel was chosen because a core theme is the pliability of language, and how wordsmithing in the service of trivial or life-endangering purposes can render words and language devoid of meaning. In Orynx and Crake human life has mostly been removed from the planet by a biological disaster, caused by a virus encysted in a pleasure product called BlyssPluss. In this desolated world, with its stark dangerous sun, Jimmy tries to survive. He scavenges for anything useful to his marginal existence. He tries to escape the attacks of laboratory-created animals such as wolvogs and pigoons who now roam freely and fiercely. Revealing the background to this disaster, step by step, Atwood explores how corporate power has used science, technology and force to shape and control society. 
One theme is how language was being used in the society that later collapsed. Jimmy, working for a company called AnooYoo, had been a copywriter for self-improvement and 'health' products, depicting their selling features and helping to create demand for them. This was a second-tier job, inferior to working directly with science. Jimmy spent his 10-hour working days 'wandering in the labyrinths of the thesaurus and cranking out the verbiage' (p. 291). He made up words - 'tensicity, fibracionous, pheromoimal' (p. 292) - but no one noticed. His life was disintegrating:

He knew he was faltering, trying to keep his footing. Everything in his life was temporary, ungrounded. Language itself had lost its solidity; it had become thin, contingent, slippery, a viscid film on which he was sliding around like an eyeball on a plate. An eyeball that could still see, however. That was the trouble. (pp. 305-6)

The novel pursues the theme of lost words. They have no meaning because what they referred to is now gone forever. Jimmy can no longer take delight or comfort in the lists of obsolete words he can recite.

Making connections with gender, leadership and sustainability. How words move from radical intent and potential to co-option is intriguing but familiar. This has happened to many feminist terms. It is happening now to those evoking emotions as they become tamed in the language of emotional intelligence. It is happening as ecological collapse becomes depicted, and accepted in a way, as 'climate change'; as CSR becomes familiar, its dimensions mapped; as 'sustainability' is applied widely, and often read as only financial viability. Words alone are inadequate to resist a technological society. How do we keep words alive? Is academic scholarship, with its increasing production orientation, contributing to the erosion of language, devaluing itself in the process? Words have become pliable, are required in volume and there is little encouragement for them to relate to practice or significant societal challenges.

Concerned about the disconnections of intellect and practice, Charlene Spretnak (1991) distinguishes deconstructive and ecological postmodernism. The former can invite 'detachment, displacement, and shallow engagement' as living practice (Spretnak, 1991, p. 13). Ecological postmodernism recognizes that 'all beings are structurally related' (p. 20) and connected. Spretnak argues that 'the radical implications of postmodern science' (1991, p. 20) have not yet been heeded. She advocates we develop our capacities for subtle perception of inter-connectivity and for forms of expression that can handle paradox. She suggests that the intellect can yearn but can only take us to the brink of change; that we need practices and disciplines to take us further. 


\section{The Memoirs of a Survivor by Doris Lessing (1974)}

This novel was chosen for its depiction of the everyday textures of society in crisis. It too reflects on forms of knowing. In a suburb to the north of a large city, the narrator had lived in a ground floor flat. In the novel she reflects back on this time of major social upheaval. Early on, a stranger had entrusted into her care a girl called Emily and her dog/cat companion Hugo. (I will not account here for the parallel world the narrator can enter through the flat's wall or the novel's autobiographical associations.)

Previous notions of social order were slipping away, with new forms arising. Brief phrases show what had become ordinary. All public services had stopped in the south and east, where bands of people lived on what they could find. Buildings had ceased functioning as machines. Scenes were lit by candlelight. Finding food and resources involved foraging as much as purchasing. Occasionally word spread that a rubbish tip from the ambivalent 'Age of Affluence' (p. 96), had been opened, providing supplies. The narrator watched travelling bands gather on the pavement opposite. They mingled and left with essential possessions, heading westwards into the country. Word never returned that any had found better circumstances. People clung to what was previously considered normal: 'I played the game of complicity like everyone else. I renewed my lease ... for seven years: of course I knew that we didn't have anything like that time left' (p. 96). 'The authorities' are distant, talking about situations but ineffectual. They descend occasionally to impose control but are dangerous to ordinary citizens who now live by workable but illegal arrangements.

Lessing critiques limited rational intelligence. The narrator appreciates Hugo's sense of awareness, capacity for love, contrasting this with 'our thoughts, our intellectual apparatus, our rationalisms and our logics' (p. 74). Speaking from the future she says: 'as we sit in the ruins of this variety of intelligence, it is hard to give it much value ... we are undervaluing it now as we overvalued it then' (p. 74).

Gender relations were affected by the turbulence, reverted. Young men became leading figures, young women their helpers, competing to be their sexual partners, caring for the displaced children. Emily is referred to on the street as 'Emily, Gerard's girl' (p. 146).

Making connections with gender, leadership and sustainability. Memoirs reflects the politics of everyday life. It questions what forms social order might take in times of limited resources, fragmenting society. There is violence but also social order and connection, for example, the sharing of news and sensemaking on the street corner. The novel questions gender roles. As in Mara and Dann, these become more stereotyped. It also explores forms of intelligence, what we know and how we allow ourselves to not know until what has been tacit is expressed almost inadvertently. Almost gently, but 
systematically, many aspects of industrial growth societies are critiqued. Memoirs provides a potential evocation of society, even in currently affluent countries, a decade or so hence, after encountering fossil fuel scarcity (Heinberg, 2005) and significant climate change, unless social organization has risen to the challenges.

\section{Prodigal Summer by Barbara Kingsolver (2000)}

This novel was chosen because it is a treatise on ecology and living in, and protecting, the natural world. Through the activities of its different characters, it reflects the dilemmas of controlling or appreciating abundant nature. It explores issues of gender and different forms of knowing, for example, contrasting the more rational and instrumental approach of commercial farming with methods that let nature flourish.

In the forested mountains and struggling small farms of southern Appalachia in the USA we meet a diverse range of characters who, variously, seek to protect the return of coyote (a keystone predator); love insects, bugs and moths and the conditions that enable them to thrive; decide to farm goats rather than tobacco; seek to restore the now extinct American chestnut tree to the landscape through cross-breeding; and grow apple orchards without pesticides.

One theme is the physical, embodied resonance of people and other creatures. This is shown, for example, in the device of opening and closing the novel with similarly worded sections describing bodily alertness and pleasure in nature, attuned to context, the former about Deanna, the mountain ranger, the latter depicting the coyote.

Making connections with gender, leadership and sustainability. Prodigal Summer is an ecological treatise, and thus more didactic than many novels. It advocates fitting into nature and explores the practices, forms of knowing and social formations of doing so. Through the novel we can consider what it might mean to take fitting in as our informing base. Kingsolver emphasizes the embodiment of our connection with nature and how we hold that physically and sensuously. She portrays debates about gender and forms of action in the interplay between characters. She appears more affirming of some female characters' senses of systemic understanding of nature than of most of the men's. Some reviews of the novel are critical about this; some treat it as a question worth exploring. The text includes 'lectures' on ecology and working with nature, for example, outlining the ecological importance of moths and explaining how removing a keystone predator from an ecosystem reduces the diversity of species from many to a few as the balance of relationships is changed. 


\section{Woman on the Edge of Time by Marge Piercy (1979)}

This novel was chosen because it depicts a possible future in which frugality and gender and racial equality are fundamental. Published in 1979 it is a highly prescient analysis. Connie is in an asylum for the mentally unstable and socially wayward, treated with drugs and a brain implant. Poverty, race and gender contribute to her being placed so vulnerably in society. She is taken by a guide, Luciente, into a future society, Mattapoisett, in 2137 and learns about its practices and underpinning philosophies. This form calls for explanations, a device allowing Piercy to be didactic.

Mattapoisett incorporates many practices of frugality and equality. There is rain-water storage, solar panels on roofs, energy and resource recycling and regional self-sufficiency in protein production. People are explicitly repairing the damage of 'The Age of Greed and Waste' (p. 55). Luxuries are scarce and so are shared round, by credit schemes individually or regionally. 'Per' is the personal pronoun rather than 'he' or 'she'. Both women and men 'mother', biologically (by artificial reproduction) and socially. 'Every child has three. To break the nuclear bonding' (p. 105). There is equality in societal role-taking. Everyone contributes to care and life sustaining tasks and is also creatively expressive. Social systems support these principles and practices. 'Government' is enacted through local decision-making processes that include advocates for the earth and for animals, and people debate until they agree. Key life transitions are marked by ceremonies and rituals.

Making connections with gender, leadership and sustainability. Piercy depicts us as currently making choices that are fateful, as Atwood and Kingsolver also do. Connie briefly travels to a harsh alternative future in which technology has been used to address society's ills but gendered roles and inequalities are accentuated. This is a warning. We have, Piercy thinks, the capacity to choose differently. She emphasizes that environmental sustainability and equality, in terms of gender and race, are thoroughly interwoven, and must be set within social systems that support them. The novel addresses issues of power. In Mattapoisett women have relinquished their centrality in reproduction for equality to be achieved.

Woman on the Edge of Time offers a thought-through analysis of a frugal and restorative society. It shows the necessary integrations between material and social processes, the need fundamentally to address issues of equality and power to support everyday practices of sustainability. People engage in their own creativity but also enact a radical understanding of integrating, socially and with nature. This could be termed a radical feminist view of an alternative social order (Calás and Smircich, 2006) and this would fit its date of publication. The attention to making micro-practices of everyday life congruent with overarching philosophy seems to me robust, communicating a sensibility that makes me think, at least temporarily, in its terms, for example, 
seeing the abundant use of resources as strange and mentally using 'per'. I wonder what we now consider necessary to human existence, that Mattapoisett will not fulfil; perhaps, for some, the speed of communication, a sense of stimulation.

\section{Discussion}

This article sought to proliferate images relevant to leadership for sustainability and weave them through with gender-associated appreciations. Below I draw out some tentative contributions relevant to en-gendering leadership in environmentally challenging times. If change for sustainability is possible, this analysis leads me to suggest we focus less attention on organizations and CSR, despite corporate economic power, and attribute more importance to broader notions of society and the textures that do or do not support certain patterns of living. These are intimately connected with practices of equality or inequality. Within these settings, corporations will or will not be held to account.

Drawing on the novels' imagery, I suggest we might create more propitious grounds for sustainability if we value multiple forms of knowing and place analytic intelligence alongside but not superior to other forms; acknowledge ourselves as fundamentally embodied; cultivate our attentions so that we can see and behold the world, recognizing how we construct our representations; relinquish our acquiescence to corporate and organizational life as being the life and place it back in a wider context; radically explore what it means to live embedded in nature and take this knowing to the heart of what we do; and cultivate our systemic senses of connection with other humans and with the more-than-human world, learning to live by them. As long as we leave the dominance of instrumental reasoning unchallenged other issues will always be difficult to address. This is a challenge to academia as currently configured, as much as to other sectors of society. I see these as significantly, but subtly, gender-associated issues. They place gender and other relations of (in)equality as central in addressing sustainability and corporate responsibility. The themes above provide cues for an alternatively gendered view of leadership for sustainability.

If we look to society rather than organizations to construct notions of sustainability we see the potential for different patterns of gender and leadership. Reversing figure and ground in this way takes me, as illustration, to the Women's Environmental Network (WEN, n.d.) a UK-based charity seeking to educate, inform and empower women and men who care about the environment. WEN provides information and campaigns on a range of topics, including waste, health, food and cloth nappies for babies, that save 40 per cent of carbon emissions over disposable alternatives (Environment Agency Report, 2008). Its Women's Manifesto on Climate Change was produced 
jointly with the National Federation of Women's Institutes and published in May 2007 with 300,000 individual and organizational signatories (WEN and National Federation of Women's Institutes, 2007).

Are voices such as WEN's readily heard in a society that has given so much primacy to corporate power? What would it take for WEN, and others speaking from a similar grounding, to routinely formulate climate change action alongside corporate CEOs - or to make the latter report regularly to the former as a form of organizational accountability?

There are dangers in the analysis so far; it might risk re-stereotyping women as caring, relational and more. But there are other possibilities. An alternative, more strident, formulation is that we have to re-conceive ourselves as humans-in-connection with the other beings in the world. Ecofeminists are not alone in proposing this but their root attention to issues of equality is especially significant. Urging that 'we must find another relationship to nature besides reification and possession', Haraway (1992, p. 296) explores how we might engage with respect in a politics, and epistemology, which does not place people and 'nature' as 'other', created as objects from an expert distance. We should eschew this 'political semiotics of representation' (p. 309), and explore instead 'a possible politics of articulation' (p. 311) in which those involved are engaged actors, respected for their collective voices. In relation to the Amazon, she explores how to engage the voices of indigenous people, the rubber tappers, the jaguar, seeking a space 'elsewhere' ( $\mathrm{p}$. 313) to make this possible, not in realism but appreciating representational practices. She asserts:

The fundamental point is that the Amazonian Biosphere is an irreducible human/non-human collective entity. There will be no nature without justice. Nature and justice, contested discursive objects embodied in the material world, will become extinct or survive together. (Haraway, 1992, p. 311).

With her different language and conceptualization, Plumwood (2002) explores similar issues of how we have separated ourselves in self-destructive and other-destroying ways. Reason has failed in relation to the ecological crisis, she says, because of limited knowledge, poor political structures and inadequate, human-centred worldviews and ethics. While privilege confers some remoteness from ecological damage it is a short-term solution. 'Remoteness from the consequences of destroying nature is the ultimate illusion. If the world of nature dies, Wall Street dies too' (Plumwood, 2002, p. 236).

Arguing that we need to recognize 'our ecological embeddedness and vulnerability' (p. 239), Plumwood suggests that

we need a cultural paradigm shift in many linked areas to adopt a partnership or dialogical model of relationships with nature in place of currently disabling centrist control.... This task is urgent. (p. 238) 
The tasks and epistemologies of reconnecting that Haraway and Plumwood urge are profoundly challenging. What then does this imply for leadership for sustainability? Whose leadership? In what world? Seen from this perspective, the leadership of tempered radicals in current organizations is a valuable but perhaps temporary focus, creating time for alternative forms of leadership to emerge. Haraway's and Plumwood's analyses suggest that we, as those affirming leadership in others and in ourselves, need to listen for the more radical views of those with a grounded, egalitarian approach to reforming society. We can expect their language to be expressive as much as rational. And we might want to ensure that they are not replicating the gendered, heroic patterns of leadership to which we have, it seems, become so addicted.

I close, as I opened, pondering urgency. If ecological issues and climate change are still highly contested, how much more difficult it seems to raise overtly the interwoven gendering of taking action, including leadership, for sustainability. In the haste to save the planet it seems tempting to avoid gendered wars and potential misunderstandings. We do not have the time. But perhaps we have no other option. D'Eaubonne (cited in Cooper, 1992) argues that no revolution led by masculine qualities in society (rather than men per se) will address the destruction of natural resources. She poses the choice as 'feminism or death' — 'Le Féminisme ou la mort' (d'Eaubonne, 1974).

\section{References}

Acker, J. (1990) Hierarchies, jobs, bodies: a theory of gendered organizations. Gender and Society, 4,2, 139-58.

Acker, J. (2004) Gender, capitalism and globalization. Critical Sociology, 30,1, 17-41.

Alvesson, M. and Billing, Y.D. (2009) Understanding gender and organizations. Los Angeles: Sage.

Arena, C. (2004) Cause for Success. Novato, CA: New World Library.

Atwood, M. (2004) Oryx and Crake. London: Virago Press.

Bakan, J. (2004) The Corporation. London: Constable.

Business in the Community (n.d.) Homepage available online at www.bitc.org.uk Last accessed 17 January 2011

Calás, M.B. and Smircich, L. (2004) Revisiting 'dangerous liaisons' or does the 'feminine-in-management' still meet 'globalization'? In Frost, P.J., Nord, W.R. and Krefting, L.A. (eds) Managerial and Organizational Reality, pp. 467-81. Upper Saddle River, NJ: Pearson Prentice Hall.

Calás, M.B. and Smircich, L. (2006) From the 'woman's point of view' ten years later: towards a feminist organization studies. In Clegg, S.R., Hardy, C., Lawrence, T.B. and Nord, W.R (eds) The Sage Handbook of Organization Studies, 2nd edn. pp. 284345. Thousand Oaks, CA: Sage.

Carson, R. (1962) Silent Spring. New York: Houghton Mifflin Harcourt.

Coleman, G. (2002) Gender, power and post-structuralism in corporate citizenship. Journal of Corporate Citizenship, 1,5, 17-25.

Collinson, D. and Hearn, J. (1994) Naming men as men: implications for work, organization and management. Gender, Work E Organization, 1,1, 2-22. 
Cooper, C. (1992) The Non and Nom of Accounting for (M)other Nature. Accounting Auditing \& Accountability Journal, 5,3, 16-39.

Czarniawska, B. (2003) The styles and the stylists of organization theory. In Tsoukas, H. and Knudsen, C. (eds) The Oxford Handbook of Organization Theory, pp. 237-61. Oxford: Oxford University Press.

Czarniawska, B. (2006) Doing gender unto the other: fiction as a mode of studying gender discrimination in organizations. Gender, Work \& Organization, 13,3, 234-53.

D’Eaubonne, F. (1974) Le Féminisme ou la mort. Paris: Pierre Horay.

Environment Agency Report (2008) An Updated Lifecycle Assessment Study for Disposable and Reusable Nappies available online at http://randd.defra.gov.uk/ Document.aspx?Document=WR0705_7589_FRP.pdf Last accessed 29 November 2010.

Elkington, J. (1997) Cannibals with Forks: the Triple Bottom Line of 21st Century Business. Oxford: Capstone.

Gore, A. (2006) An Inconvenient Truth: a Global Warning. London: Bloomsbury.

Gray, R. and Milne, M. (2004) Toward reporting on the triple bottom line: mirages, methods and myths. In Henriques, A. and Richardson, J. (eds) The Triple Bottom Line: Does It All Add Up? pp. 70-80. London: Earthscan.

Grosser, K. (2009) Corporate social responsibility and gender equality: women as stakeholders and the European Union sustainability strategy. Business Ethics: A European Review, 18,3, 290-307.

Haraway, D. (1992) The promises of monsters: a regenerative politics for inappropriate/d others. In Grossberg, L., Nelson, C. and Treichler, P. (eds) Cultural Studies, pp. 295-337. New York: Routledge.

Harding, S. (2006) Animate Earth: Science, Intuition and Gaia. Totnes: Green Books.

Hardy, C. and Clegg, S.R. (1996) Some dare call it power. In Clegg, S., Hardy, C. and Nord, W.R. (eds) Handbook of Organization Studies, pp. 622-41. London: Sage.

Hawken, P. (1993) The Ecology of Commerce. New York: Harper Business.

Heinberg, R. (2005) The Party's Over: Oil, War and The Fate of Industrial Societies. Gabriola Island: New Society Publishers.

Henriques, A. and Richardson, J. (2004) The Triple Bottom Line: Does It All Add Up? London: Earthscan.

Intergovernmental Panel on Climate Change (2007) Climate Change 2007: Synthesis Report. Fourth Assessment. Core Writing Team, Pachauri, R.K. and Reizinger, A. (eds). Geneva: IPCC available at http://www.ipcc.ch/publications_and_data/ publications_ipcc_fourth_assessment_report_synthesis_report.htm Last accessed 29 November 2010.

Kingsolver, B. (2000) Prodigal Summer. London: Faber and Faber.

Kanter, R.M. (1977) Men and Women of the Corporation. New York: Basic Books.

Korten, D.C. (1995) When Corporations Rule the World. London: Earthscan.

Lessing, D. (1976) The Memoirs of a Survivor. London: Picador.

Lessing, D. (1999) Mara and Dann. London: Flamingo.

Lovelock J. (2006) The Revenge of Gaia. London: Allen Lane.

Macy, J.R. and Brown, M.Y. (1998) Coming Back to Life. Gabriola Island: New Society Publishers.

Marshall, J. (2007) The gendering of leadership in corporate social responsibility. Journal of Organizational Change Management, 20,2, 165-81.

Marshall, J. (2008) Finding form in writing for action research. In Reason, P. and Bradbury, H. (eds) Handbook of Action Research (2nd edn) pp. 682-94. London: Sage.

Meadows, D.H., Randers, J. and Meadows, D.L. (2004) Limits to Growth: The 30-Year Update. White River Junction, VT: Chelsea Green. 
Meyerson, D.E. and Scully, M.A. (1995) Tempered radicalism and the politics of ambivalence and change. Organization Science, 6,5, 585-600.

Millennium Ecosystem Assessment (2005) Ecosystems and Human Well-being: Synthesis. Washington, DC: Island Press available at http://www.maweb.org/documents/ document.766.aspx.pdf Last accessed 29 November 2010.

Monbiot, G. (2006) Heat: How to Stop the Planet Burning. London: Allen Lane.

Piercy, M. (1979) Woman on the Edge of Time. London: Women's Press.

Plumwood, V. (2002) Environmental Culture: The Ecological Crisis of Reason. London: Routledge.

Porritt, J. (2007) Capitalism as If the World Matters. Earthscan: London.

Rockström, J., Steffen, W., Noone, K. et al. (2009) A safe operating space for humanity. Nature, 461,7263, 472-5.

Schumacher, E. [1973] (1993) Small is Beautiful: A Study of Economics As If People Mattered. London: Vintage.

Spretnak, C. (1991) States of Grace. New York: HarperSanFrancisco.

Waring, M. (1988) If Women Counted. San Francisco, CA: Harper and Row.

Weick, K.E. (1989) Theory construction as disciplined imagination. Academy of Management Review, 14,4, 516-31.

Women's Environmental Network (WEN) (n.d.) Homepage available at http:// www.wen.org.uk/ Accessed 17 January 2011.

WEN and National Federation of Women's Institutes (2007) Women's Manifesto on Climate Change available at http://www.wunrn.com/news/2007/09_07/ 09_10_07/091607_womens_files/091607_womens.pdf Last accessed 17 January 2011. 